\title{
LABORATORY EXPERIMENTS ON THE BIOLOGICAL TREATMENT OF SEWAGE.
}

\author{
By DAVID SOMMERVILLE, B.A., M.D., M.R.C.P. Lond., D.P.H. Camb.
}

From the State Medicine Laboratories, King's College, London.

Мuch has been written in recent years on the biological treatment of sewage, and various have been the views advanced regarding the mode of action and comparative results of aerobic and anaerobic bacteria. The enthusiasm with which particular modifications of centact beds, septic tanks, etc., have been $\mathrm{\epsilon xploited,} \mathrm{arises} \mathrm{more} \mathrm{from} \mathrm{fancy,} \mathrm{it} \mathrm{is}$ to be feared, than from accurate knowledge of the changes productd, and the results obtained in any individual case.

The exact chemistry of the purification of sewage, as indeed of the so-called "oxidation of organic matter" in any form, is still obscure, and with this particular chapter of science $I$ have at present nothing to do, further than to admit, that evidence exists to show that during the initial, intermediate, and final stages of sewage purification, highly complex organic molecules in the presence of oxygen, bacteria, moisture, and a suitable temperature, are transformed into comparatively simple inorganic equivalents; and that although the net result may still be broadly described as effected by "processes of oxidation " there is no doubt that, as in other forms of fermentation, the end is reached through manifold alternating steps of oxidation and reduction. At a future date I may have something to say concerning the chemistry of certain intermediate products of purifying sewage.

In looking broadly at present day methods of sewage purification, one recognizes two main stages, viz., an initial, in which a sufficient quantity of the solids of crude sewage are liquefied, in order to fit it for passing into the second stage, viz., that of filtration through fine contact beds, where the treatment is more or less completed.

It seems to be in connection with the first stage that differences of opinion exist as to the comparative merits of various methods, some maintaining that the septic tank method is the best, others that coarse contact beds are preferable, whilst a third class of observers hold to a combination of these two.

Other things being equal, it must be admitted that of the different forms of initial stage adopted, that which best disposes of the sludge problem and at the same time minimizes the formation of malodorots gases, must command universal respect.

That the septic tank emits foul odours is only to be expected, when it is remembered that the action of anaerobic micro-organisms on 
organic matter is ever attended by the formation of evil-smelling gases. Aerobes perform their functions in a much less objectionable manner.

Mr. W. J. Dibdin has recently suggested a method for first stage operations, in which the disagreeable features of the septic tank are avoided. He employs as material for a coarse contact bed, slabs of waste slate, laid horizontally in rows, which are separated from each other, and supported by slate blocks.

It is found that the bed need only be half the size of a coke bed, much greater space obtaining for the growth and action of aerobic organisms; the bed can be most easily cleansed, and foul smells are completely absent. A film of oxygen is retained on the under surface of the slabs as the sewage gradually fills the bed. Loss of capacity. which largely occurs in coke and clinker beds, is reduced to nothing, as the material does not settle together, break down, nor impair drainage. Bacteria grow on both sides of the slates, and none of the intervening spaces can be choked as in coke beds.

The immediate object of the experiments to be described was to determine the degree of purification, as measured by decrease in albuminoid ammonia, corresponding with definite spaces between the slabs of slate, with the view of establishing if possible an optimum space.

Crude sewage, obtained through the kindness of Dr. Clowes from the London outfall, was used throughout. Operations were carried out in two laboratory tanks of different sizes, containing horizontal rows of slate slabs, arranged at distances apart, varying from one to twelve inches. Care was taken that the conditions of temperature, time given to filling and emptying the tank, time of contact of sewage with slates, etc., were as nearly as may be constant. The temperature was maintained at $16^{\circ}-18^{\circ} \mathrm{C}$. Half an hour was allowed for filling a tank, half an hour for emptying, and two hours for undisturbed contact. Five hours were allowed for rest.

The optimum vertical space between the rows of slabs as indicated by these experiments appears to be about four inches. A few examples selected from a large number of results will serve to make this manifest.

My thanks are due to Prof. Smith for introducing this work.

\begin{tabular}{|c|c|c|}
\hline No. of Experment. & $\begin{array}{c}\text { Distance between rows } \\
\text { of slabs }\end{array}$ & $\begin{array}{l}\text { Percentage reduction of } \\
\text { Alb. Ammonia. }\end{array}$ \\
\hline 5 & 1 inch & 25 \\
\hline 7 & 2 inches & 31 \\
\hline 11 & 2 & 30 \\
\hline 17 & 3 & 50 \\
\hline 19 & 3 & 52 \\
\hline $2 k$ & 4 & 56 \\
\hline 29 & 6 & 45 \\
\hline 35 & 12 & 18 \\
\hline 37 & 12 & 17 \\
\hline
\end{tabular}

